\title{
BIODEGRADATION OF ACETONITRILE BY CELLS OF CANDIDA GUILLIERMONDII UFMG-Y65 IMMOBILIZED IN ALGINATE, א-CARRAGEENAN AND CITRIC PECTIN
}

\author{
João Carlos T. Dias; Rachel P. Rezende and Valter R. Linardi \\ Departamento de Microbiologia, Instituto de Ciências Biológicas, Universidade Federal de Minas Gerais, \\ Belo Horizonte, MG, Brasil
}

Submitted: October 08, 1999; Returned to authors for corrections: December 06, 1999; Approved: January 11, 2000

\begin{abstract}
Different encapsulation matrices were tested for immobilized cells of Candida guilliermondii UFMG-Y65 used for acetonitrile degradation. Acetonitrile degradation by free cells and cells immobilized in Ba-alginate, $\kappa$-carrageenan and citric pectin was studied. The rate of acetonitrile degradation was monitored for $120 \mathrm{~h}$ by measuring yeast growth and ammonia concentration. Different alginate concentrations did not affect cell viability, but the period of incubation in $\mathrm{BaCl}_{2}$ solution reduced the number of viable cells. Likewise, the gel nature and the matrix structure of the support resulting from the cell immobilization conditions were of fundamental importance for biocatalyst activity and performance, affecting substantially the patterns of microbial growth and enzymatic activity. Alginate-immobilized cells degraded acetonitrile more efficiently than $\mathrm{K}$-carrageenan or citric pectin-immobilized cells.
\end{abstract}

Key words: Candida guilliermondii, acetonitrile, biodegradation, immobilization

\section{INTRODUCTION}

The biological degradation of nitriles proceeds through two enzymatic routes. Nitrilase (E.C. 3.5.5.1) catalyses the direct cleavage of nitriles to yield the corresponding acids plus ammonia, whereas nitrile hydratase (E.C. 4.2.1.1.84) catalyses the hydration of nitriles to amides, which are subsequently hydrolyzed to acids and ammonia by amidase (E.C.3.5.1.4). The hydrolysis of nitrile by microbial nitrile hydratase has been exploited for the commercial production of acrylamide (12). Recently attention has been directed towards regio-and/or stereoselective nitrile hydrolysis by, for example, Brevibacterium imperiale B222 (4), Pseudomonas spp. (15).

The potential of using immobilized cells in industrial processes is regarded as a valuable application $(9,5)$. Cells at different stages (viable, resting, dead etc.) have been successfully encapsulated in various matrices $(17,6,21)$. Bioremediation using cells has been widely investigated for numerous toxic chemicals such as phenol (3), pentachlorophenol (20), acetonitrile (8) and acrylamide (18). In the practical utilization of living cells encapsulated in hydrophilic gels, important factors affect microbial metabolism and the efficiency of the system such as diffusion of essential nutrients, oxygen transfer, physical and chemical properties of the gel and immobilization procedure. Immobilized cells in hydrophilic gels have received a lot of attention in environmental applications. Although it is not possible to make a general statement about the behavior of microorganisms in hydrophilic gels. The literature data are not uniform, but vary according to the type of microorganism, immobilizing matrix and productive system (7). In the present study, biodegradation of acetonitrile using immobilized Candida guilliermondii UFMG-Y65 in various matrices was investigated and compared with that obtained with freely suspended cells. The influence of time of incubation in $\mathrm{BaCl}_{2}$ solution on cell viability, and of alginate concentration was also investigated.

\footnotetext{
* Corresponding author. Mailing address: Departamento de Microbiologia, ICB-UFMG, Caixa Postal 486, CEP 31270-901 Belo Horizonte, MG, Brasil. Email: linardiv@mono.icb.ufmg.br
} 


\section{MATERIALS AND METHODS}

Microorganism. The yeast was isolated from water samples collected from gold extraction circuit (Mineração Morro Velho, Nova Lima, Brazil) according to Linardi et al. (16). The strain was characterized by standard methods, and identified as Candida guilliermondii by keys reported by Kreger-van Rij (13) and Barnett et al. (2) and by molecular methods performed as described by Lachance et al. (14). The strain was maintained on GYMP slant medium (- w/v - $2 \%$ glucose, $0.5 \%$ yeast extract, $1 \%$ malt extract, $0.2 \% \mathrm{NaH}_{2} \mathrm{PO}_{4}$, and $2 \%$ agar) under a mineral oil layer and stored at $4^{\circ} \mathrm{C}$, or in liquid nitrogen.

Cell mass preparation. In order to obtain microbial suspensions of high cellular density the C. guilliermondii UFMG-Y65 strain was inoculated into $250 \mathrm{ml}$ Erlenmeyer flasks containing $50 \mathrm{ml}$ Yeast-Carbon-Base (YCB-Difco) plus $6 \%$ acetonitrile as sole nitrogen source. The flasks were incubated under shaking at $120 \mathrm{rpm}$, for 120 hours at $25^{\circ} \mathrm{C}$.

Determination of cell concentration. Cell growth was determined by 2 different methods. In the first case, an appropriately $0.1 \mathrm{ml}$ aliquot of the sample was distributed on the surface of Sabouraud agar. After $72 \mathrm{~h}$ of incubation at $30^{\circ} \mathrm{C}$, the number of colonies grown was determined and, the results were expressed as colony forming units $/ \mathrm{ml}$ solution $(\mathrm{CFU} / \mathrm{ml})$. In the second method, sample dry weight was determined by two different procedures. The samples of free cells were centrifuged for 10 minutes at $5000 \mathrm{rpm}$, and washed twice in deionized water. The cells were then resuspended in $1 \mathrm{ml}$ deionized water and dried for 48 hours at $80^{\circ} \mathrm{C}$. The dry weight of gel capsules and cells, was determined by the methods of Wada et al. (22), $1 \mathrm{ml}$ of capsules was washed with $50 \mathrm{ml}$ of deionized water and dried by the same procedure as described for free cells.

Effect of barium chloride and potassium chloride on the growth of $\boldsymbol{C}$. guilliermondii UFMG-Y65. To $250 \mathrm{ml}$ Erlenmeyer flasks containing $50 \mathrm{ml}$ of minimum medium $(-\mathrm{w} / \mathrm{v}-0.1 \%$ $\mathrm{K}_{2} \mathrm{HPO}_{4} ; 0.02 \% \mathrm{MgSO}_{4} 7 \mathrm{H}_{2} \mathrm{O}$ and, $0.01 \% \mathrm{NaCl}$ ) enriched with $1.0 \mathrm{M}$ acetonitrile, we added either $\mathrm{BaCl}_{2}$ or $\mathrm{KCl}$ at concentrations of 5, 25, 50, 100 or $200 \mathrm{mM}$ and inoculated with $1.0 \mathrm{ml}$ of a cell suspension of $C$. guilliermondii UFMG-Y65 $\left(A_{480}=0.155\right)$. Cultures were incubated at $25^{\circ} \mathrm{C}$ in a rotary shaker at $120 \mathrm{rpm}$ for $72 \mathrm{~h}$. In each experiment, the growth was estimated by measuring $\mathrm{CFU} / \mathrm{ml}$, and the ammonia concentration in the supernatant was measured according to Fawcett and Scott (11).

Immobilization of yeast cells by encapsulation on different support materials. Alginate $(4.25 \%$, w/w) (Vetec Fine Chemistry Ltda), $2.13 \%$ K-carrageenan (Sigma Chemical Co.) and $2.13 \%$ citric pectin, low methoxy (Braspectina - Citrus Colloids S/A), suspensions of polymers of similar viscosity, were dissolved in $18 \mathrm{ml}$ of distilled water. After sterilization at $120^{\circ} \mathrm{C}$ for $15 \mathrm{~min}$, the polymer suspensions were added to aliquots of $6 \mathrm{ml}$ containing $10^{8} \mathrm{cell} / \mathrm{ml}$ at $40^{\circ} \mathrm{C}$ for $\kappa$-carrageenan gel and at $30^{\circ} \mathrm{C}$ for alginate and pectin gels. The suspensions were forced out with the aid of a hypodermic syringe of $1 \mathrm{~mm}$ of inner diameter, and dropped into $200 \mathrm{ml}$ of sterile solution of crosslinking salt at concentrations of 0.1 up to $1.0 \mathrm{M}$. $\mathrm{KCl}$ was used for the $\kappa$-carrageenan matrix and $\mathrm{BaCl}_{2}$ for citric pectin and alginate. The capsules, measuring approximately $2 \mathrm{~mm}$ in diameter, were maintained in the cross-linking solution for 10 $\min$ to $24 \mathrm{~h}$ at $10^{\circ} \mathrm{C}$. Before use, the capsules were washed with $200 \mathrm{ml}$ distilled water at $10^{\circ} \mathrm{C}$ to remove excess salt.

Influence of different polymer types. $250 \mathrm{ml}$ Erlenmeyer flasks containing $40 \mathrm{ml} 1.0 \mathrm{M}$ acetonitrile in minimum medium $\left(0.1 \% \mathrm{~K}_{2} \mathrm{HPO}_{4} ; 0.02 \% \mathrm{MgSO}_{4} 7 \mathrm{H}_{2} 0\right.$; and $\left.0.01 \% \mathrm{NaCl}\right)$ were inoculated with $10 \mathrm{ml}$ of $C$. guilliermondii UFMG-Y65 encapsulated in different matrices (alginate, $\kappa$-carrageenan, citric pectin). The assays were maintained under shaking at $120 \mathrm{rpm}$ at $25^{\circ} \mathrm{C}$ for $120 \mathrm{~h}$. After this period, the ammonia concentrations and cell growth were determined. The experiments were carried out with free cells solution using the same cell concentration as in the assays involving cells immobilization.

Influence of polymer concentration, gel bead formation time and cross-linking salt solution concentration on the process of polymeric matrix formation and on biocatalyzer activity. With the objective of evaluating the effects of these variables, we tested different gel bead formation conditions on ammonia generation, stability of matrices and growth of $C$. guilliermondii-UFMG-Y65 after $120 \mathrm{~h}$ of cultivation, as shown in Table 1.

All experiments were repeat three times and the mean values obtained are reported.

Table 1. Influence of polymer concentration, gel bead formation time and cross-linking salt solution concentration in the process of formation of the polymeric matrix

\begin{tabular}{cccc}
\hline Assay & $\begin{array}{c}\text { Alginate } \\
\text { concentration (\%) }\end{array}$ & $\begin{array}{c}\mathrm{BaCl}_{2} \\
\text { concentration }(\mathrm{M})\end{array}$ & $\begin{array}{c}\text { gel bead formation } \\
\text { time }\end{array}$ \\
\hline 1 & 2.0 & 1.0 & $10 \mathrm{~min}$ \\
2 & 2.0 & 1.0 & $60 \mathrm{~min}$ \\
3 & 2.0 & 0.1 & $14 \mathrm{~h}$ \\
4 & 2.0 & 0.1 & $24 \mathrm{~h}$ \\
5 & 4.0 & 1.0 & $10 \mathrm{~min}$ \\
6 & 4.0 & 1.0 & $60 \mathrm{~min}$ \\
7 & 4.0 & 0.1 & $14 \mathrm{~h}$ \\
8 & 4.0 & 0.1 & $24 \mathrm{~h}$ \\
\hline
\end{tabular}




\section{RESULTS AND DISCUSSION}

Barium chloride and potassium chloride are cross-linking salts for the $\kappa$-carrageenan and pectin supports, respectively. Bajpai et al. (1) suggested improvement of the culture medium with the cross-linking salt used in the manufacture of beads. According to these authors, the addition of the salt guarantees chemical stability and mechanical integrity of the gel. However, the concentrations vary according to the authors. Fig. 1 demonstrates the variations in ammonia production and in the cell growth caused by different $\mathrm{BaCl}_{2}$ and $\mathrm{KCl}$ concentrations added to the culture medium. The results indicate that the inhibitory effect of potassium ions was lower than that barium ions on ammonia generation and cell growth. Increasing concentrations of $\mathrm{BaCl}_{2}$ blocked the action of nitrilases. Nilson et al.(19) observed that bi-and trivalent cations at low concentrations are extremely toxic for the growth of microorganisms.

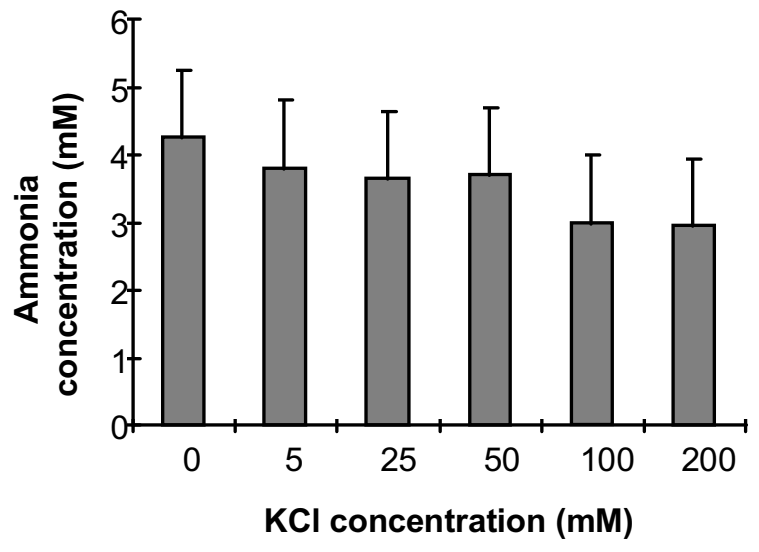

(A)

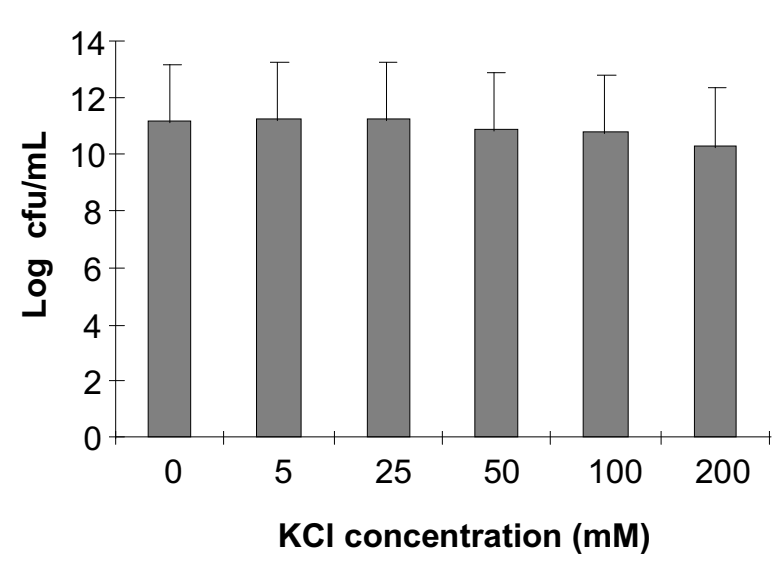

(C)
The applicability of several polymeric natural or synthetic polymers as matrices for immobilization of viable cells motivated the study of the use of hydrophilic gels such as alginate, pectin and $\kappa$-carrageenan. The effects of these types of polymer supports used for immobilization on the acetonitrile biodegradation by free and immobilized cells are demonstrated in Fig. 2 (A and B). The $\kappa$-carrageenan gel presented lower biodegradation efficiency than the alginate and pectin gels, a fact that can explained by the differences in the porous structures of the matrices, probably permitting a better growth of the cells in the alginate and pectin matrices and, as a consequence higher ammonia generation (Fig. 2 B). Besides $\kappa$-carrageenan was the one that shown the higher cell release rate into the culture medium when compared to the alginate and pectin gels (Fig. 3)

Cheetham et al. (10), immobilizing cells of Saccharomyces uvarum in calcium alginate gel, observed the influence of polysaccharide concentration and the existence of a relationship between gel bead formation time and cross-linking salt solution

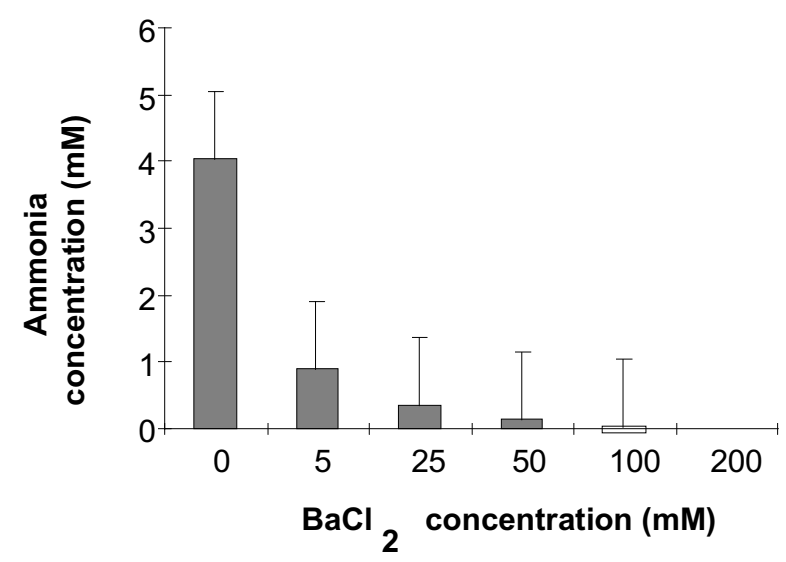

(B)

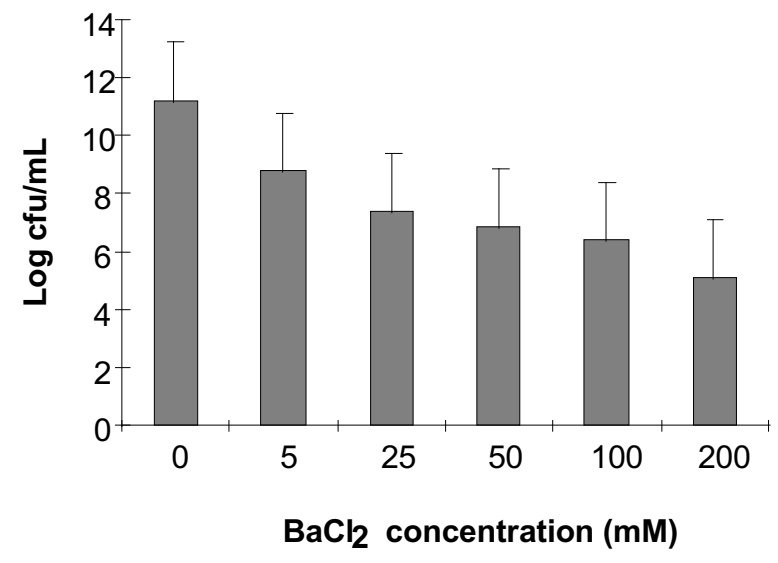

(D)

Figure 1. Influence of potassium chloride and barium chloride on ammonia generation (A and B) and growth (C and D) of C. guilliermondii UFMG-Y65 in medium containing $1.0 \mathrm{M}$ acetonitrile under shaking at $120 \mathrm{rpm}$ at $30^{\circ} \mathrm{C}$, for 120 hours. 


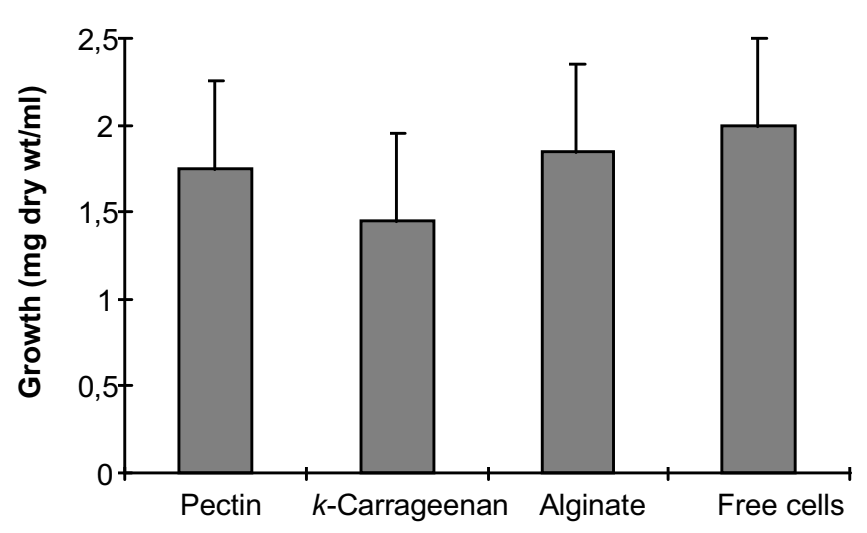

(A)

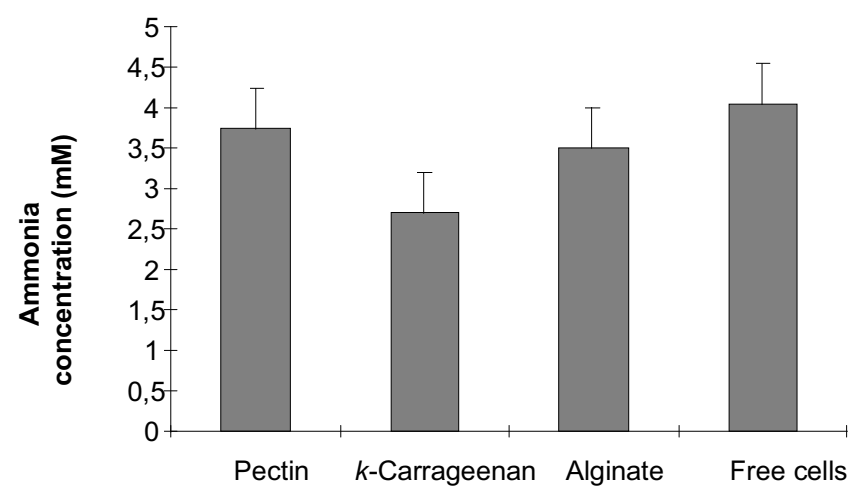

(B)

Figure 2. Influence of different types of supports on mass production (A) and ammonia generation (B), by C. guilliermondii UFMG-Y65 in 1.0 M acetonitrile, after $120 \mathrm{~h}$, under shaking at $120 \mathrm{rpm}$ at $30^{\circ} \mathrm{C}$.

concentration in the process of formation of the polymeric matrix. Fast gel bead formation processes, of the order of minutes, involve high concentrations of $\mathrm{BaCl}_{2}$. In diluted $\mathrm{BaCl}_{2}$ more time was necessary to complete the reaction. When gel bead formation processes occurs only partially, the central area of the capsule tends to stay more fluid than its surface.

Fig. 4 (A and B) shows the ammonia conversion and the concentration of cells that were released from the gel at the end of the process. For the same salt concentration and same gel bead formation time the profiles of ammonia production did not differ significantly at different polymer concentrations. After 120 hours of cultivation, practically no variation was observed in the ammonia concentration with the same polymer concentration. Cell release into the medium (Fig. 4B), however was more marked for gels with greater mechanical resistance.

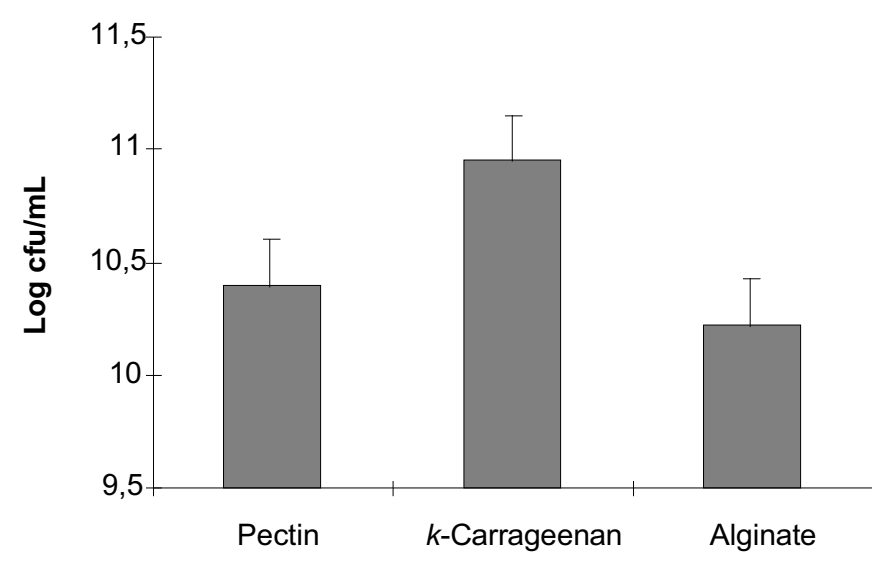

Figure 3. Influence of different types of gels on the cell release of $C$. guilliermondii UFMG-Y65, in flasks containing $1.0 \mathrm{M}$ acetonitrile after 120 $\mathrm{h}$, under shaking of $120 \mathrm{rpm}$ at $30^{\circ} \mathrm{C}$.
In the evaluation of effects of different gel bead formation types on ammonia production (Fig. $4 \mathrm{~A}$ ), the matrices that were crosslinking quickly presented lower values, possibly due to the structural difference between them and the matrices that crosslinking with different size, distribution and amounts of pores. Although there was a difference in ammonia production between fast and slow, with a fixes polymer concentration, no appreciable variations in ammonia production were observed with different gel bead formation time, for the same concentration of $\mathrm{BaCl}_{2}$. For the slowly cross-linking biocatalyser after 120 hours of incubation, a high level of cell release was observed when compared to that obtained with rapidly cross-linking matrices. This fact could be due to a smaller mechanical resistance of these matrices which reduced the effects of mass transfer. Acetonitrile conversion in ammonia (Fig. 4 A) has little effected by the increase of polymer percentage. Probably, the $\mathrm{BaCl}_{2}$ concentration is the limiting factor in such conversion. Fig. 4 (C). shows that the capacity of retention of cells inside the gel was higher for matrices with $4 \%$ polymer. The variation of polymer concentration directly affects the final structure of the matrices, but not cell viability. The salt concentration, however, significantly affects the two parameters. The liberation of cells into the culture medium, on the other hand, was quite marked for gel containing $2 \%$ alginate (Fig. $4 \mathrm{~B}$ ).

The study reveals slight increase of acetonitrile degradation by free cells of $C$. guilliermondii UFMG-Y65. Even with limited performance increase the use of immobilized cells can be considered an advantageous alternative, because it avoids the bioreactor obstruction resulting from the low resistance and small size of biomass. This culture is also capable of degrading other aromatic and aliphatic nitriles (data not shown). Thus there is a potential for the development of microbial technology for the treatment of effluents containing nitriles. 


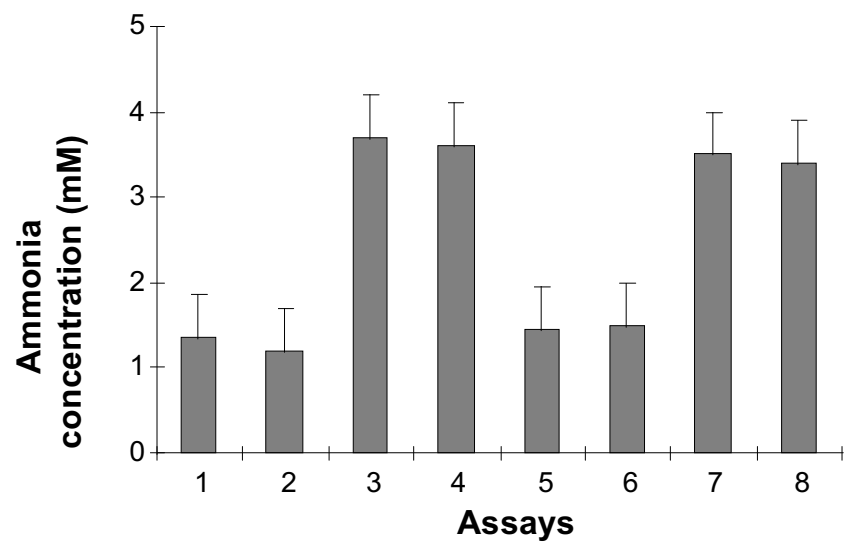

(A)

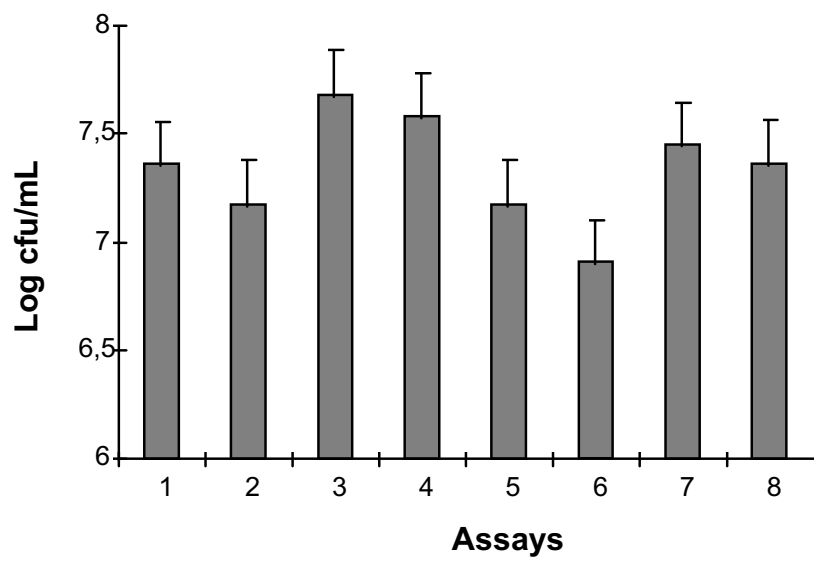

(B)

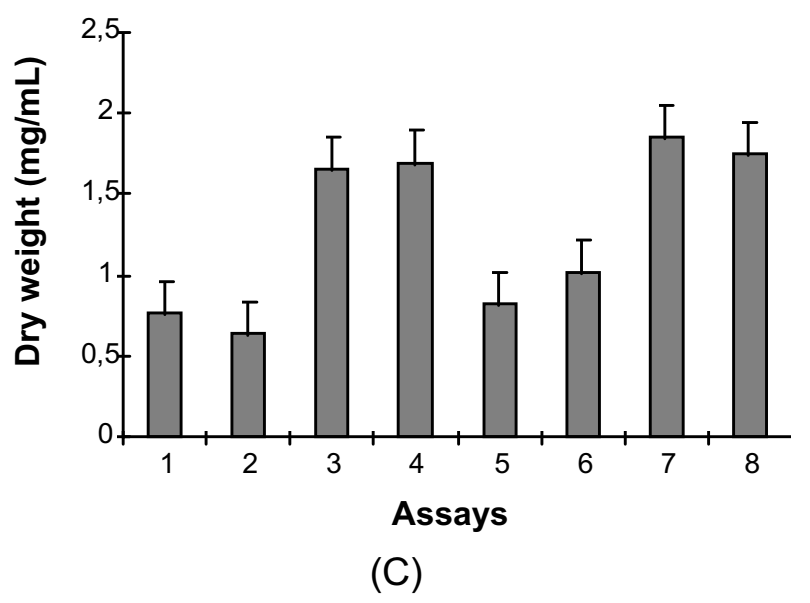

Figure 4. Influence of alginate concentration, gel bead formation time and $\mathrm{BaCl}_{2}$ concentration on ammonia production (A), stability of the matrices (B) and growth of immobilized C. guilliermondii UFMG-Y65 (C), after 120 hours of incubation in flasks containing $1.0 \mathrm{M}$ acetonitrile with shaking at $120 \mathrm{rpm}$ at $30^{\circ} \mathrm{C}$.

\section{ACKNOWLEDGMENTS}

The authors would like to thank FAPEMIG for financial support (Proc.CBS-1001/97), CNPq for fellowships (Proc. 523158/96) and Braspectina - Citrus Colloids S/A for providing citric pectin.

\section{RESUMO}

\section{Biodegradação de acetonitrilas por células de Candida guilliermondii UFMG-Y65 imobilizadas em alginato, $\kappa$ - carrageno e pectina cítrica}

$\mathrm{Na}$ degradação de acetonitrila, foram testadas células livres de Candida guilliermondii UFMG-Y65 e imobilizadas em diferentes suportes, quais sejam, Ba-alginato, $\kappa$-carrageno e pectina cítrica. A velocidade de degradação da acetonitrila foi monitorada por $120 \mathrm{~h}$, mediante o crescimento da levedura e geração de amônia. Diferentes concentrações de alginato não afetam a viabilidade das células; mas o período de incubação, em solução de $\mathrm{BaCl}_{2}$, reduziu o número de células vivas. Da mesma forma, a natureza do gel e a estrutura da matriz do suporte, ambas resultantes das condições de imobilização das células, foram de fundamental importância para a atividade catalisadora e sua performance; afetando assim, os padrões de crescimento microbiano e a de atividade enzimática. As células imobilizadas em alginato degradaram acetonitrila com maior eficácia do que as imobilizadas em $\mathrm{\kappa}$-carrageno ou as células imobilizadas em pectina cítrica.

Palavras-chave: Candida guilliermondii, Acetonitrila, biodegradação, imobilização

\section{REFERENCES}

1. Bajpai, P. K.; Wallace, J. B.; Margarits, A. Effects of calcium cloride concentration on ethanol production and growth of immobilized Zymomonas mobilis. J. Ferment. Technol., 10: 59-65, 1988.

2. Barnett, J. A., Payner, R. W.; Yarrow, D. Yeast: Characteristics and Identification, (eds). Cambridge University Press, Cambridge, London, 1990.

3. Bettmann, H. and Rehm, H. J. Degradation of phenol by polymer entrapped microrganisms. Appl. Microbiol Biotechnol., 20: 285-290, 1984.

4. Bianchi, D., Bosetti, A., Cesti, P., Fransozi, G.; Spezia, S. Stereoselective microbial hydrolysis of 2-aryoxypropionitriles. Biotechnol. Lett. 10: 402408, 1991

5. Bisping, A.; Rehm, H. J. Muitistep reactions with immobilized microorganisms. Biotechnol Appl. Biochem. 10: 87-98, 1988.

6. Brodelius, P., Vandamme, E. J. Immobilized cells $I n$ : Kennedy, J. F. (ed) Biotechnology, vol. 7 ${ }^{\text {a }}$. VCH. Weinheim, 1987, p. 405-464.

7. Cassidy, M. B.; Lee, H.; Trevors, J. T. Environmental applications of immobilized microbial cells: a review. J. Industrial Microbiol. 16: 79101, 1996.

8. Chapatwala, K.D.; Babu, G. R. V.; Dudley, C.; Williams, R.; Aremu, K Degradative capability of Pseudomonas putida on acetonitrile. Appl. Biochem. Biotechnol., 39/40:655-665, 1993. 
9. Cheetham, P. S. J. Developments in immobilized cells and their applications. In: Wiseman, A. (ed) Topics in enzyme and fermentation technology, vol. 4. Elllis Horwood. Chichester.1980, p. 189-238.

10. Cheetham, P. S. J.; Blunt, K. W.; Christopher, B. Physical studies on cell immobilization using calcium alginate gels. Biotechnol. Bioeng., 21: 21552168, 1979.

11. Fawcett, J. K.; Scott, J. E. A rapid method for the determination of urea. $J$ Clin Pathol., 13: 156-160, 1960.

12. Kobayashi, M., Nagasawa, T.; Yamada, H. Enzymatic synthesis of acrylamide: a success story not yet over. Trends Biotechnol., 10: 402-408, 1992.

13. Kreger-van Rij, N. J. W. The Yeast- A Taxonomic Study, 3th ed. Elservier Science Publischers BV, Amaterdam, 1984.

14. Lachance, M. A., Rosa, C. A., Starmer, W. T., Schalag-Edler, B., Barker, J. S. F.; Bowles, J. M. Metschnikowia continentalis var. borealis, Metschnikowia continentalis var. continentalis and Metschnikowia hibisici, new heterothalic yeasts from ephemeral flowers and associated insects. Can. J. Microbiol., 44: 279-288, 1998.

15. Layh, N., Stolz, A., Foster, S., Effenberger, F.; Knackmuss, H. J. Enantioselective hydrolysis of O-acety-mandelonitrile to O-acetylmandelic acid by bacterial nitrilases. Arch. Microbiol., 158: 405-411, 1992.
16. Linardi, V. R.; Dias, J. C. T.; Rosa, C. A. Utilization of acetonitrile and other aliphatic nitriles by a Candida famata. FEMS Microbiol Lett., 144: 67-71, 1996.

17. Mattiasson, B. Immobilization methods In: Mattiasson, B. (ed) Immobilized cells and organelles. Vol. 1, CRC Boca Raton. Floa. 1983, p. 3-25.

18. Nawas, S. M.; Heinze, M. T.; Cerniglia, E. C. Metabolism of acrylamide by immobilized cells of Pseudomonas sp. and Xanthomonas maltophilia. Can. J. Microbiol., 39: 207-212, 1992.

19. Nilsson, I.; Ohlson, S.; Haggstrom, L.; Molin, N. Denitrification of water using immobilized Pesudomonas denitrificans cells. Eur. J. Appl. Microbiol., 58: 27-31, 1980.

20. O'Reilly, K. T.; Crawford, R. L. Degradation of pentachlrophenol by polyurethane-immobilized Flavobacterium cells. Appl. Environ. Microbiol., 55: 2113-2118, 1989.

21. Trevors, J. T.; Elsas, J. D. van; Lee, H.; Overbeek, L. S. van. Use of alginate and otheir carriers for encapsulation of microbial cells for use in soil. Microb. Release, 1: 61-69, 1992.

22. Wada, M.; Kato, J.; Chibata, I. Electron microscopic observation of immobilized growing yeast cells. J. Ferment. Technol., 58: 78-85, 1980. 